\title{
OCCURRENCE OF SELECTED ORGANOCHLORINE PESTICIDE RESIDUES IN SURFACE SEDIMENTS FROM THE VELKE KOZMALOVCE, RUZIN, AND ZEMPLINSKA SIRAVA WATER RESERVOIRS, SLOVAKIA
}

\author{
EDGAR HILLER ${ }^{1 *}$, MAROŠ SIROTIAK ${ }^{2)}$, VERONIKA TATARKOVÁ $^{1)}$, L’UBOMÍR JURKOVIČ $^{1)}$ \\ ${ }^{1)}$ Comenius University in Bratislava, Faculty of Natural Sciences, Department of Geochemistry, Mlynska dolina, \\ 84215 Bratislava 4, Slovak Republic; ${ }^{*}$ Correspondence author, Mailto: hiller@fns.uniba.sk, phone: +421 2/602 96218 , \\ fax: +421260296217. \\ ${ }^{2}$ Institute of Safety and Environmental Engineering, Department of Environmental Engineering, Faculty of Materials Science \\ and Technology in Trnava, Slovak University of Technology in Bratislava, Botanicka 49, Trnava 917 24, Slovak Republic.
}

Surface sediment samples from three water reservoirs of Slovakia were analyzed for selected organochlorine pesticides (OCPs). Concentrations of total dichlorodiphenyltrichloroethanes ( $\mathrm{DDDTs}$ ) in the sediments from Velke Kozmalovce, Ruzin, and Zemplinska Sirava ranged from 12 to $24 \mathrm{ng} \mathrm{g}^{-1}, 5$ to $28 \mathrm{ng}$ $\mathrm{g}^{-1}$, and 1 to $20 \mathrm{ng} \mathrm{g}^{-1}$, respectively, with the exception of one sediment sample from Zemplinska Sirava, having anomalously high concentration of $\Sigma$ DDTs $\left(526 \mathrm{ng} \mathrm{g}^{-1}\right)$. Concentrations of hexachlorobenzene (HCB) in the sediments from these water reservoirs were generally lower and ranged from 0.3 to $9 \mathrm{ng} \mathrm{g}^{-1}$. Other organochlorine pesticides such as mirex, lindane and heptachlor were not detected in the surface sediments. Ratios of DDT/(DDE + DDD) were lower than 1.0 in majority of the sediment samples indicating that the degradation of the parent DDT occurred significantly and DDT in the sediments from the studied water reservoirs was derived mainly from the weathered agricultural soils. Moreover, ratios of DDD/DDE indicated that the parent DDT was degraded under aerobic conditions before depositing into the sediments of these water reservoirs.

KEY WORDS: Organochlorine Pesticides, DDT, Surface Sediments, Water Reservoir, Organic Matter.

Edgar Hiller, Maroš Sirotiak, Veronika Tatarková, Lubomír Jurkovič: VÝSKYT REZÍDUÍ VYBRANÝCH ORGANOCHLÓROVANÝCH PESTICÍDOV V SEDIMENTOCH Z VODNÝCH NÁDRŽÍ VELKÉ KOZMÁLOVCE, RUŽÍN A ZEMPLÍNSKA ŠÍRAVA, SLOVENSKO. J. Hydrol. Hydromech., 59, 2011, 1; 45 lit., 2 obr., 4 tab.

V štúdii boli analyzované vzorky sedimentov z troch vodných nádrží Slovenska na vybrané organochlórované pesticídy (OCPs). Koncentrácie sumy DDT a jeho metabolitov DDE a DDD (LDDTs) v sedimentoch z vodných nádrží Vel'ké Kozmálovce, Ružín a Zemplínska Šírava sa nachádzali v intervale od 12 do $24 \mathrm{ng} \mathrm{g}^{-1}$, od 5 do $28 \mathrm{ng} \mathrm{g}^{-1}$ a od 1 do $20 \mathrm{ng} \mathrm{g}^{-1}$, s výnimkou jednej vzorky sedimentu zo Zemplínskej Š́ravy, ktorá vykazovala anomálne vysokú koncentráciu 2 DDTs (526 ng g-1). Koncentrácie hexachlórbenzénu (HCB) v sedimentoch z týchto vodných nádrží boli všeobecne nižšie a pohybovali sa $\mathrm{v}$ intervale od 0,3 do $9 \mathrm{ng} \mathrm{g}^{-1}$. Iné $\mathrm{v}$ sedimentoch sledované organochlórované pesticídy ako mirex, lindán a heptachlór neboli zistené. Vo väčšine vzoriek sedimentov boli hodnoty pomeru DDT/(DDE + DDD) nižšie ako $1, \mathrm{z}$ čoho sa dá usúdit', že väčšia čast' pôvodne prítomného DDT sa rozložila na jeho hlavné metabolity a že DDT v sedimentoch vodných nádrží pochádza najmä z erodovaných pol'nohospodárskych pôd. Hodnoty pomeru DDD/DDE ukázali, že predtým ako bol DDT deponovaný do sedimentov vodných nádrží, rozkladal sa najmä za aeróbnych podmienok.

KLÚČOVÉ SLOVÁ: organochlórované pesticídy, DDT, dnové sedimenty, vodná nádrž, organická hmota.

\section{Introduction}

Organochlorine pesticides (OCPs) are an important class of environmental organic pollutants that are commonly found in all regions of the world, even in such a regions where OCPs never have been used such as the Arctic, Antarctica and others (Muir et al., 1995; Klánová et al., 2008; Wang et al., 2008). The organochlorine pesticides are in general very hydrophobic substances with low 
aqueous solubility and high octanol-water partition coefficients ranging from 3 to 7 (Wania, Mackay, 1995; Paasivirta et al., 1999). As a consequence of their physico-chemical properties, these pesticides tend to accumulate mainly in "natural" organic matter of the soils, sediments and living organisms (Menone et al., 2006; Chi, 2009; Zhao et al., 2009), and have a long persistence in the environment. Although the production and usage of OCPs were banned early in 1980s in Europe, they are belonging to the most prevalent pollutants of rivers, lakes, soils, aquatic sediments and food (Covaci et al., 2002; Peris et al., 2005; Bettinetti et al., 2006; Pulkrabová et al., 2008; Villaverde et al., 2008). Therefore, these organic pollutants could still represent a potential threat to biota and human health due to their well-known high toxicity and other adverse effects, such as endocrine disruption (Edwards, 1987; WWF, 1999).

Sediments have been identified as an important reservoirs of persistent organochlorine pesticides and act as both an ultimate sinks and potential sources for further contamination of overlying waters with OCPs. Highly variable concentrations of OCPs in sediments are usually observed even in a small area of studied sites since concentrations of these chemicals may be affected by a combination of several inputs and factors, such as agricultural runoff, wastewater discharge, atmospheric deposition, physico-chemical and biological properties of sediments (e.g. total organic carbon content, $\mathrm{pH}$, redox conditions, microbial communities and their activity) and temperature.

Taking into account the above and the fact that a variety of OCPs with the long-term persistence was used on the territory of former Czechoslovakia a few decades ago, one may still expect an occurrence of these chemicals in various compartments of the environment. Therefore, the aim of this study was to investigate the occurrences and concentrations of selected OCPs (DDT isomers and their metabolites, hexachlorobenzene, $\gamma-\mathrm{HCH}$ (lindane), heptachlor and mirex) residues in surface sediments of the Velke Kozmalovee, Ruzin and Zemplinska Sirava water reservoirs that are situated in the Slovak Republic in order to evaluate the status and possible sources of pollution, as well as the potential biological effects of OCPs on aquatic biota living in the study areas.

\section{Materials and methods}

\subsection{Study areas and sample collection}

Fig. 1 shows the study areas and the sampling locations. The Ruzin water reservoir with an area of $3.9 \mathrm{~km}^{2}$ and a water volume of $59 \times 10^{6} \mathrm{~m}^{3}$ lies at the northwest of Kosice, eastern Slovakia. Two rivers enter the reservoir: Hornad and Hnilec. The two rivers drain the Spiš-Gemer Rudohorie Mts., the area with long-time mining activities, oretreatment and procesing industrial activities. Moreover, numerous urban waste discharges drain directly into the rivers. The reservoir of Velke Kozmalovce with an area of $0.62 \mathrm{~km}^{2}$ and a total water volume of $2.7 \times 10^{6} \mathrm{~m}^{3}$ lies on the Hron River near the village of Stary Tekov, western Slovakia (Fig. 1). The Hron River receives organic pollutants from direct discharges of industrial waste waters and atmospheric deposition. As a consequence, the sediments of Velke Kozmalovce were found to be highly contaminated with polycyclic aromatic hydrocarbons (Hiller et al., 2009). The largest reservoir is Zemplinska Sirava with an area of $15.1 \mathrm{~km}^{2}$ and a water volume of $185 \times 10^{6} \mathrm{~m}^{3}$. It lies at the northeast of Michalovce in eastern Slovakia and serves for flood-control, irrigation and recreational purposes. Kocan et al. (2001) have shown that the Zemplinska Sirava is highly contaminated with polychlorinated biphenyls produced by the Chemko chemical factory (Strazske) during the period of 1959-1984. Sediment samples $(0-20 \mathrm{~cm})$ were collected using a stainless-steel corer in June 2005 from the 6, 19 and 9 locations in Velke Kozmalovce, Ruzin and Zemplinska Sirava water reservoirs, respectively (Fig. 1). Sediment samples in Ruzin reservoir were taken from its two sedimentation basins as shown in Fig. 1. These sedimentation basins are located at sites of the inflows of Hornad and Hnilec rivers into the Ruzin reservoir. After collection, all samples were transferred to a glass jars and stored at $-20^{\circ} \mathrm{C}$ until extraction. Frozen aliquots of sediment samples were air dried and then ground and sieved through a $2 \mathrm{~mm}$ sieve before analysis.

\subsection{Sample analysis}

Total organic carbon (TOC) contents were determined using a CS analyser (Metalyt CS 100/100, Eltra, FRG). The analyses of OCPs were performed 


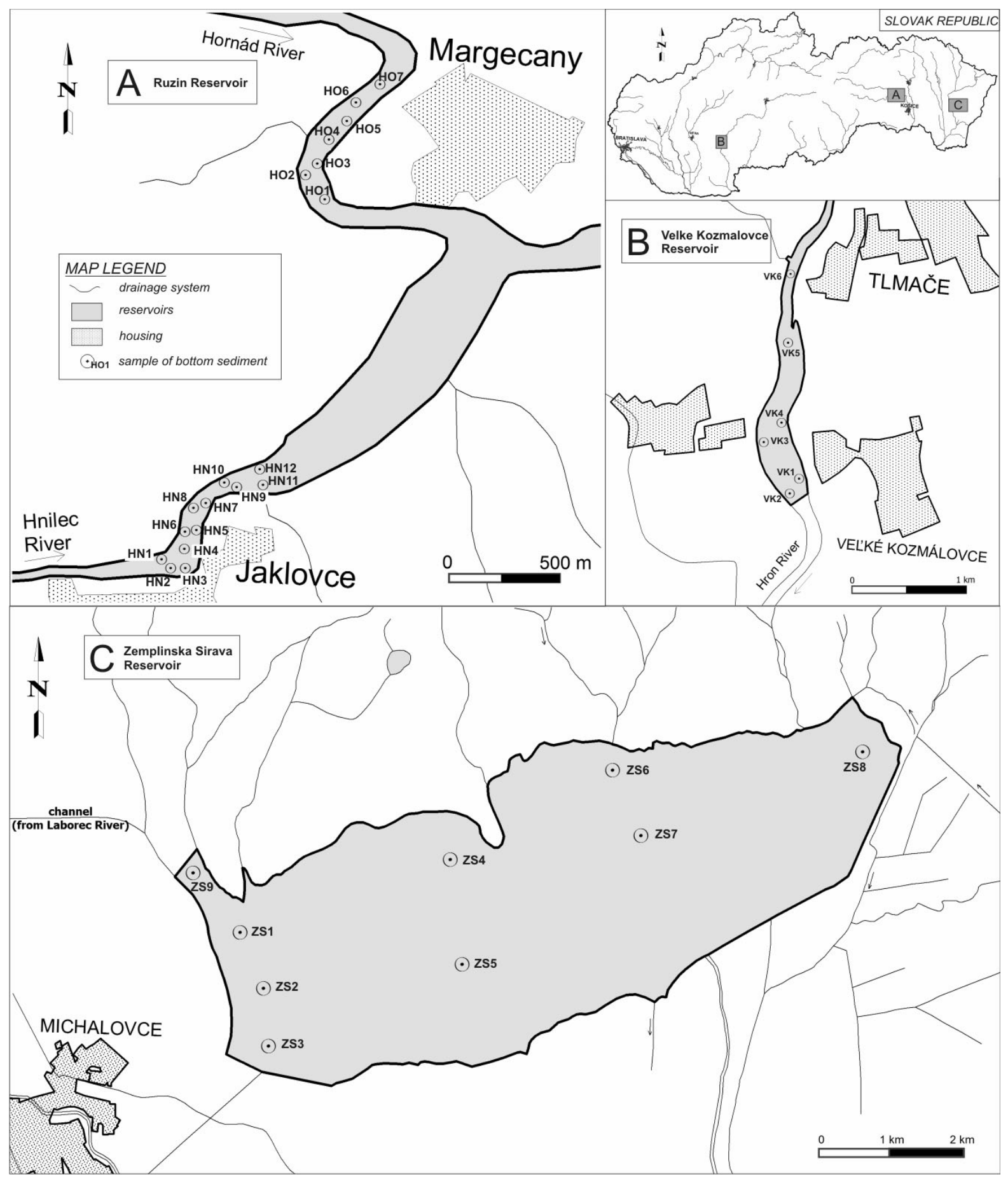

Fig. 1. The locations of sampling sites of the sediment samples.

at the accredited laboratory of the Czech Geological Survey, branch Brno, Czech Republic. Briefly, $10 \mathrm{~g}$ of sediment was extracted by ultrasonication for 60 min with $30 \mathrm{ml}$ mixture of $\mathrm{n}$-hexane and acetone $(1: 1 \mathrm{v} / \mathrm{v})$ in two cycles. The extracts were centrifuged at $4000 \mathrm{rpm}$ for $15 \mathrm{~min}$ and combined. The extract was passed through a column filled with anhydrous $\mathrm{Na}_{2} \mathrm{SO}_{4}$ to remove residues of water, and then eluted with $\mathrm{n}$-hexane and acetone mixture $(1: 1 \mathrm{v} / \mathrm{v})$. The extracts were concentrated using Turbovap evaporator (Zymark, USA) to approximately $2 \mathrm{ml}$ and chromatographically purified on a 
column filled with acidified silica gel and activated copper fillings. The elution of OCPs was done with a mixture of dichloromethane and n-hexane $(1: 10$ $\mathrm{v} / \mathrm{v})$. The eluate was concentrated to near dryness and the final extract was re-solubilized in isooctane.

The determination of OCPs was performed on a HP 5890 series II gas chromatograph equipped with an ${ }^{63} \mathrm{Ni}$ electron capture detector and $\mathrm{HP}$ Chemstation software package. A HP-5 capillary column $(60 \mathrm{~m} \times 0.25 \mathrm{~mm}$ i.d., $0.25 \mu \mathrm{m})$ was used. The chromatographic conditions were as follows: carrier gas was hydrogen and volume of sample injected in splitless mode was $1 \mu \mathrm{l}$. The temperature program was as follows: initial temperature $60^{\circ} \mathrm{C}$ held for $2 \mathrm{~min}$, increased to $120^{\circ} \mathrm{C}$ at a rate of $5^{\circ} \mathrm{C} / \mathrm{min}$, isothermal at $120^{\circ} \mathrm{C}$ for $2 \mathrm{~min}$, followed at $30^{\circ} \mathrm{C} / \mathrm{min}$ to $180^{\circ} \mathrm{C}$ and then $3^{\circ} \mathrm{C} / \mathrm{min}$ to $280^{\circ} \mathrm{C}$. The injector temperature was $280^{\circ} \mathrm{C}$. Detection limits were $0.1 \mathrm{ng} \mathrm{g}^{-1}$ for HCB, $o, p^{\prime}$-DDT, $p, p^{\prime}-$ DDD and $o, p^{\prime}$-DDD, $0.3 \mathrm{ng} \mathrm{g}^{-1}$ for both DDE isomers and $0.5 \mathrm{ng} \mathrm{g}^{-1}$ for $p, p^{\prime}$-DDT with relative standard deviation of $<15 \%$. The procedure was checked for recovery efficiences by analyzing uncontaminated sediment spiked with known quantity of OCPs standard. Recovery efficiences ranged from $82 \%$ up to $99 \%$ depending on the individual OCP compounds.

\section{Results and discussion}

\subsection{Residues of OCPs}

\subsubsection{DDT and its metabolites DDE and DDD}

In this study, concentrations of the following organochlorine pesticides in surface sediments were determined: DDT isomers, DDT degradation products $\mathrm{DDE}\left(p, p^{\prime}\right.$-DDE $+o, p^{\prime}$-DDE) and $\mathrm{DDD}\left(p, p^{\prime}-\right.$ $\mathrm{DDD}+o, p^{\prime}$-DDD), hexachlorobenzene (HCB), heptachlor, mirex and $\gamma-\mathrm{HCH}$ (lindane). However, OCPs such as heptachlor, mirex and lindane were detected in none of the surface sediment samples, and therefore, these OCPs were not discussed in this study.

Concentrations of the parent DDT, its metabolites and the total organic carbon (TOC) contents are shown in Tab. 1. Notable differences could be observed between the concentrations of the parent DDT in sediments from Zemplinska Sirava reservoir and those found in sediments from the other two water reservoirs (Tab. 1). The parent DDT was detected only at 1 site (ZS6) of Zemplinska Sirava while relatively high detection frequency of these compounds was obtained in the other two water reservoirs. It is speculated here that this difference might be due to the different degradation rates of DDT. Earlier report on DDT degradation showed that DDT degraded faster in soils with the lower TOC contents than in those with the high TOC contents (Wang et al., 2006). TOC contents in the surface sediments of Zemplinska Sirava are generally much lower when compared with those in the sediments of Velke Kozmalovce and Ruzin, and this might be a reason of the enhanced degradation rate of DDT in Zemplinska Sirava resulting in its low detection frequency.

The status of pollution of surface sediments with total DDTs in this study was compared with those in other freshwater ecosystems of the world (Tab. $2)$. Concentrations of total dichlorodiphenyltrichloroethanes ( $\Sigma$ DDTs) in the sediments from Velke Kozmalovce, Ruzin, and Zemplinska Sirava water reservoirs ranged from 12 to $24 \mathrm{ng} \mathrm{g}^{-1}, 5$ to $28 \mathrm{ng} \mathrm{g}^{-1}$, and 1.3 to $20 \mathrm{ng} \mathrm{g}^{-1}$, respectively, with the exception of one sediment sample from Zemplinska Sirava, having anomalously high concentration of LDDTs $\left(526 \mathrm{ng} \mathrm{g}^{-1}\right)$. Our results were comparable to the data reported for sediments collected from ponds and Horní Bečva water reservoir in Czech Republic (Boháček et al., 2003; Svobodová et al., 2003) and some other regions over the world such as Danube Delta, Romania (Covaci et al., 2006), Bosomtwi Lake, Ghana (Darko et al., 2008) and Yen So Lake, Vietnam (Hoai et al., 2009). On the other hand, the concentrations of $\Sigma$ DDTs measured in this study were lower than those in sediments near serious point source discharges, e.g. in Norway and India where a total DDT concentrations of 193000 and $5630 \mathrm{ng} \mathrm{g}^{-1}$ have been measured in bottom sediments, respectively (Brevik et al., 1996; Agarwal et al., 1986) or in sediments from such a regions where a recent usage of DDT was assumed despite of its prohibition (Fernández et al., 2000).

Among DDT and its metabolites, $p, p^{\prime}$-DDE was the most dominant, and its concentrations were in the range of 1.3-410 $\mathrm{ng} \mathrm{g}^{-1}$, accounting for the largest percentage of the total DDTs with a mean value of $55 \%, 83 \%$, and $92 \%$ in Velke Kozmalovee, Ruzin, and Zemplinska Sirava water reservoirs, respectively. This indicates the high stability of $p, p^{\prime}$-DDE in the sedimentary environment as compared to the parent compound $p, p^{\prime}$-DDT and other metabolites. It could be seen from Tab. 1 that 
among the DDT compounds, the $p, p^{\prime}$ isomers were much more abundant than the $o, p^{\prime}$ isomers. This is a common feature of DDT composition, and in freshly synthesized DDT the $o, p^{\prime}$ isomers may reach up to $12-20 \%$ of the total DDT (WHO, 1989). However, the $o, p^{\prime}$-DDT isomer undergoes a relatively rapid isomerization to $p, p^{\prime}$-DDT and its proportion decreases (Gaggi et al., 1985).

$\mathrm{T}$ a b $1 \mathrm{e}$ 1. Concentrations (ng g ${ }^{-1}$ dry wt.) of hexachlorobenzene (HCB), DDT isomers and their degradation products in surface sediment samples from Velke Kozmalovce, Ruzin, and Zemplinska Sirava water reservoirs.

\begin{tabular}{|c|c|c|c|c|c|c|c|c|c|}
\hline Sample & $\mathrm{HCB}$ & $p, p^{\prime}$-DDT & $o, p^{\prime}$-DDT & $p, p^{\prime}$-DDE & $o, p^{\prime}$-DDE & $p, p^{\prime}$-DDD & $o, p^{\prime}$-DDD & DDTs $^{\mathrm{c}}$ & TOC \\
\hline \multicolumn{10}{|c|}{ Velke Kozmalovce } \\
\hline VK1 & 2.8 & 2.9 & 0.9 & 9.8 & 0.2 & 0.5 & bdl & 14.3 & 8.72 \\
\hline VK2 & 2.2 & 13.0 & 0.8 & 9.2 & 0.2 & 0.5 & bdl & 23.7 & 7.14 \\
\hline VK3 & 2.4 & 5.9 & 0.9 & 9.3 & 0.2 & 0.3 & bdl & 16.6 & 7.62 \\
\hline VK4 & 0.7 & 12.8 & 0.6 & 5.5 & bdl & 1.3 & bdl & 20.2 & 6.12 \\
\hline VK5 & 9.2 & 2.7 & 0.4 & 8.7 & 0.2 & bdl & bdl & 12.0 & 6.69 \\
\hline VK6 & 3.3 & 2.3 & 0.5 & 8.4 & 0.2 & 0.8 & bdl & 12.2 & 7.39 \\
\hline Mean & 3.43 & 6.60 & 0.68 & 8.48 & 0.20 & 0.68 & & 16.5 & 7.28 \\
\hline $\mathrm{SD}^{\mathrm{a})}$ & 2.96 & 5.05 & 0.21 & 1.54 & 0.00 & 0.39 & & 4.67 & 0.88 \\
\hline \multicolumn{10}{|c|}{ Ruzin-Hnilec } \\
\hline HN1 & 1.1 & 0.7 & 0.5 & 7.7 & 0.2 & bdl & bdl & 9.1 & 6.41 \\
\hline $\mathrm{HN} 2$ & 0.8 & 0.9 & 1.5 & 8.6 & 0.2 & 0.3 & bdl & 11.5 & 7.02 \\
\hline HN3 & 0.6 & 1.1 & 0.4 & 7.8 & 0.2 & bdl & bdl & 9.5 & 7.40 \\
\hline HN4 & 1.3 & 0.4 & bdl & 8.6 & 0.2 & 0.3 & bdl & 9.5 & 5.99 \\
\hline HN5 & 0.5 & 1.7 & bdl & 2.4 & bdl & 0.5 & bdl & 4.6 & 2.26 \\
\hline HN6 & 1.0 & 0.5 & bdl & 4.2 & bdl & 0.3 & bdl & 5.0 & 4.59 \\
\hline HN7 & 9.0 & 0.5 & bdl & 5.9 & 0.2 & 0.3 & bdl & 6.9 & 5.73 \\
\hline HN8 & 1.8 & bdl & bdl & 7.9 & 0.2 & 0.3 & bdl & 8.4 & 5.52 \\
\hline HN9 & 1.0 & bdl & bdl & 4.8 & bdl & bdl & bdl & 4.8 & 6.42 \\
\hline HN10 & 1.3 & 0.8 & bdl & 6.1 & 0.2 & bdl & bdl & 7.1 & 6.00 \\
\hline HN11 & 1.5 & 0.5 & bdl & 7.6 & 0.2 & 0.3 & bdl & 8.6 & 6.62 \\
\hline HN12 & 0.9 & bdl & bdl & 4.6 & bdl & bdl & bdl & 4.6 & 5.55 \\
\hline Mean & 1.73 & 0.79 & 0.80 & 6.35 & 0.20 & 0.33 & & 7.47 & 5.79 \\
\hline $\mathrm{SD}$ & 2.32 & 0.41 & 0.61 & 2.00 & 0.00 & 0.08 & & 2.32 & 1.34 \\
\hline \multicolumn{10}{|c|}{ Ruzin-Hornad } \\
\hline HO1 & 2.6 & 0.5 & bdl & 10.9 & 0.3 & 0.5 & bdl & 12.2 & 3.46 \\
\hline $\mathrm{HO} 2$ & 2.5 & 0.7 & bdl & 10.4 & 0.3 & 0.6 & bdl & 12.0 & 3.64 \\
\hline $\mathrm{HO} 3$ & 2.8 & 1.9 & bdl & 12.1 & 0.3 & 1.2 & bdl & 15.5 & 3.20 \\
\hline $\mathrm{HO} 4$ & 2.2 & 0.4 & bdl & 13.2 & 0.5 & 0.4 & bdl & 14.5 & 3.54 \\
\hline HO5 & 2.6 & bdl & bdl & 10.7 & 0.3 & 0.3 & bdl & 11.3 & 3.54 \\
\hline HO6 & 2.5 & 15.1 & 0.7 & 9.4 & 0.3 & 2.3 & bdl & 27.8 & 4.00 \\
\hline HO7 & 3.3 & 0.6 & bdl & 12.7 & 0.3 & 0.6 & bdl & 14.2 & 3.24 \\
\hline Mean & 2.64 & 3.20 & 0.70 & 11.3 & 0.33 & 0.84 & & 15.4 & 3.52 \\
\hline SD & 0.34 & 5.86 & & 1.36 & 0.08 & 0.70 & & 5.70 & 0.27 \\
\hline \multicolumn{10}{|c|}{ Zemplinska Sirava } \\
\hline $\mathrm{ZS1}$ & 1.1 & bdl & bdl & 6.8 & bdl & bdl & bdl & 6.8 & 2.20 \\
\hline $\mathrm{ZS} 2$ & 1.2 & bdl & bdl & 8.6 & bdl & 0.6 & bdl & 9.2 & 2.07 \\
\hline $\mathrm{ZS} 3$ & 1.0 & bdl & bdl & 9.9 & bdl & 0.8 & bdl & 10.7 & 1.73 \\
\hline ZS4 & 0.9 & bdl & bdl & 16.3 & bdl & 0.7 & bdl & 17.0 & 2.97 \\
\hline ZS5 & 1.3 & bdl & bdl & 16.1 & bdl & 1.3 & bdl & 17.4 & 1.79 \\
\hline ZS6 & 2.6 & 8.5 & 5.3 & 410 & 7.6 & 53.3 & 41.2 & 526 & 1.81 \\
\hline ZS7 & 0.8 & bdl & bdl & 19.0 & bdl & 1.3 & bdl & 20.3 & 3.93 \\
\hline ZS8 & 0.3 & bdl & bdl & 1.3 & bdl & bdl & bdl & 1.3 & 0.74 \\
\hline ZS9 & 0.6 & bdl & bdl & 2.2 & bdl & 0.6 & bdl & 2.2 & 1.97 \\
\hline Mean & 1.09 & 8.50 & 5.30 & $54.5(10.0)^{\mathrm{b}}$ & 7.6 & 8.37 & 41.2 & $67.9(10.7)^{b}$ & 2.13 \\
\hline $\mathrm{SD}$ & 0.65 & & & $133(6.62)$ & & 19.8 & & $172(7.02)$ & 0.89 \\
\hline
\end{tabular}

${ }^{\mathrm{a})}$ Standard deviation, ${ }^{\mathrm{b})}$ Numbers in parentheses are the means and standard deviations calculated without sample ZS6, ${ }^{\mathrm{c}}$ Sum of $p, p^{\prime}-$ DDT, $o, p^{\prime}$-DDT, $p, p^{\prime}$-DDE, $o, p^{\prime}$-DDE, $p, p^{\prime}$-DDD and $o, p^{\prime}$-DDD. 
$\mathrm{T}$ a b 1 e 2. Concentrations of total DDTs (ng g ${ }^{-1}$ dry wt.) in the surface sediments of several freshwater ecosystems from different countries and their comparison to the data reported in this study.

\begin{tabular}{lll}
\hline Locations & DDDTs & Reference \\
\hline Horní Bečva reservoir, Czech Republic & $1.2-13.5$ & Boháček et al. (2003) \\
Ponds in Bohemia, Czech Republic & $0.7-143$ & Svobodová et al. (2003) \\
Lower Oder River, Poland & $9.2-13.8$ & Tomza-Marciniak, Witczak (2009) \\
Scheldt River, Belgium & $6.6-27.6$ & Covaci et al. (2005) \\
Lakes in Danube Delta, Romania & $0.9-17$ & Covaci et al. (2006) \\
Cinca River, Spain & $9.0-94$ & de la Cal et al. (2008) \\
Southeast Regional Park in Madrid, Spain & $20.3-1185$ & Fernández et al. (2000) \\
Lake Bosomtwi, Ghana & $15.1-31.9$ & Darko et al. (2008) \\
Yen So lake, Hanoi, Vietnam & $17-109$ & Hoai et al. (2009) \\
Lake Ørsjøen, Norway & $0.6-193000$ & Brevik et al. (1996) \\
Jamuna River, India & $7-5630$ & Agarwal et al. (1986) \\
Velke Kozmalovce reservoir, Slovakia & $12-23.7$ & This study \\
Ruzin reservoir, Slovakia & $4.6-27.8$ & This study \\
Zemplinska Sirava reservoir, Slovakia & $1.3-20.3(526)$ & This study \\
\hline
\end{tabular}

\subsection{2 $\mathrm{HCB}$}

Hexachlorobenzene (HCB) was used mainly as a selective fungicide in Czech and Slovak Republic, but its use has been banned since 1985 (Čepková et al., 2003). Recently, there are no commercial uses of HCB, however, it is still released into the environment as a by-product or impurity from the production of industrial chlorinated chemicals such as carbon tetrachloride, trichloroethylene, and pentachlorobenzene. HCB was detected in all surface sediment samples and the concentrations ranged from 0.3 to $9.2 \mathrm{ng} \mathrm{g}^{-1}$ with a mean value of $2.2 \mathrm{ng}$ $\mathrm{g}^{-1}$ (Tab. 1). The higher concentrations were found in sediment samples from Velke Kozmalovce and Ruzin water reservoirs while the lower concentrations were detected in sediment samples from Zemplinska Sirava. The HCB concentrations of this study are comparable to the concentrations in sediments from Domasa water reservoir and Ondava River (eastern Slovakia) ranging from 0.04 to 2.5 $\mathrm{ng} \mathrm{\textrm {g } ^ { - 1 }}$ with a mean of $1.2 \mathrm{ng} \mathrm{g}^{-1}$ but lower than those in sediments collected around the chemical factory Chemko Strazske with a mean of $10.2 \mathrm{ng} \mathrm{g}^{-1}$ (Mackových et al., 2003).

\subsection{Sources of DDT}

The ratios between the parent compound and its metabolites can be used to identify the possible sources of DDT (sum of $p, p^{\prime}$-DDT and $o, p^{\prime}$-DDT) in the aquatic environment (Guo et al., 2009). Once released into the environment, DDT slowly degrades to DDE and DDD under aerobic and anaerobic conditions, respectively (Aislabie et al., 1997), and hence the ratios between the parent DDT and the sum of DDE and DDD is often used as an indication of the age (recent or historic) of the source of DDT (Qian et al., 2006). A small ratio of DDT/(DDE + DDD) indicates historical DDT application when there has been plenty of time to occur significant degradation of the parent DDT, whereas a value greater than 2 indicates recent use of DDT (Ma et al., 2008). In the present study, the ratios of DDT/(DDE + DDD) were in the range of 0.03 to 1.97 with the mean value of 0.41 , implying that degradation of the parent DDT occurred significantly and there is no recent input of DDT to the sedimentary environments of these water reservoirs. Moreover, the ratio of DDD/DDE can reveal the degradation pathways of DDT (Doong et al., 2002) since DDE and DDD are the aerobic and anaerobic degradation products of DDT, respectively. As shown in Fig. 2, DDD/DDE ratios in all the surface sediments were much lower than 1 , and there were also eight sites without DDD detected. This indicates that most of the parent DDT was degraded under aerobic conditions in soils before depositing into the sediments of the water reservoirs as well as these surface sedimentary environments exhibited relatively aerobic conditions.

\subsection{Correlation between total organic carbon (TOC) and concentrations of OCPS}

It is well-known that organochlorine pesticides tend to bind mainly with organic matter present in the sediments because of their hydrophobicity and low water solubility (Toul et al., 2003). Therefore, the sediment TOC has been regarded as a key property influencing concentrations of OCPs in sediments (Malik et al., 2009). In this study, there were a positive correlations between TOC contents and DDE concentrations in sediments from all the water 
reservoirs investigated (Tab. 3). Concentrations of total DDTs (sum of DDT and its metabolites) in sediments from Zemplinska Sirava and RuzinHnilec reservoirs were also significantly correlated with TOC contents. This suggests that the distribution of DDE as the main degradation product of DDT in the water reservoirs may be controlled mainly by the distribution of organic matter in the sediments. The results agree well with those reported by Hong et al. (2008), Hu et al. (2009) and Malik et al. (2009). On the other hand, there were no significant correlations between HCB concentrations in each of the water reservoirs and TOC contents (Tab. 3), implying that other factors, such as soil erosion, dynamics of river flows, input sources and degradation rate, might be important for the distribution of organochlorine pesticides besides the distribution of organic matter.

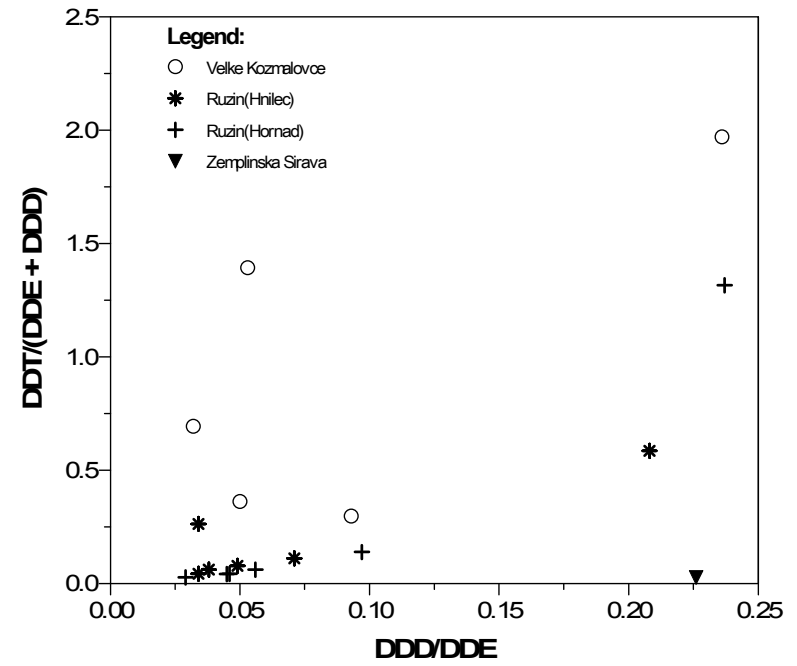

Fig. 2. Plot of the DDT/(DDE + DDD) and DDD/DDE ratios used for the identification of DDT sources.

$\mathrm{T}$ a b l e 3. Correlations between concentrations of organochlorine pesticides and TOC contents.

\begin{tabular}{lllllll}
\hline & DDT $^{\text {a) }}$ & DDE & DDD & इDDTs & HCB & $\Sigma$ OCPs \\
\hline Ruzin-Hnilec & 0.028 & $0.776^{* *}$ & -0.870 & $0.654^{*}$ & 0.023 & 0.490 \\
Ruzin-Hornad & $\left.0.778^{*}\right)$ & -0.712 & 0.552 & 0.649 & -0.598 & 0.617 \\
Velke Kozmalovce & -0.497 & $\left.0.786^{*}\right)$ & -0.733 & -0.302 & -0.102 & -0.470 \\
Zemplinska Sirava $^{\text {b) }}$ & - & $\left.0.751^{*}\right)$ & 0.382 & $0.747^{*}$ & 0.241 & $\left.0.739^{*}\right)$ \\
\hline
\end{tabular}

${ }^{\text {a) }}$ Concentrations of DDT, DDE, and DDD in the table are the sum of $p, p^{\prime}$-DDT and $o, p^{\prime}$-DDT, $p, p^{\prime}$-DDE and $o, p^{\prime}$-DDE, and $p, p^{\prime}-$ DDD and $o, p^{\prime}$-DDD, respectively, ${ }^{\text {b) }}$ sample ZS6 with notably high concentration of total DDTs was omitted from the correlation;

${ }^{*}$ The correlation is significant at the 0.05 level (1-tailed),

${ }^{* *}$ The correlation is significant at the 0.01 level (1-tailed).

\subsection{Potential biological effects of OCPS}

To evaluate the possible ecotoxicological risks of OCPs in the study areas, frequently used sediment quality guidelines for freshwater ecosystems, i.e. the threshold effect level (TEL) and probable effect level (PEL) guidelines (MacDonald et al., 2000; CCME, 1999) were applied on the obtained data, as given in Tab. 4. TEL represents the concentration below which adverse biological effects are not expected while PEL defines the concentration above which adverse effects are expected to occur frequently (Smith et al., 1996). Concentrations of DDT and DDE were higher than the PEL values at 5 sites (VK2-4, HO6, ZS6) and 25 sites, respectively, including 5 sites of Velke Kozmalovce, 13 sites of Ruzin, and 7 sites of Zemplinska Sirava. Concentration level of DDD was over the PEL value only at 1 site (ZS6) typical of the exceptionally high concentration level of $\mathrm{DDDTs}$ (Tab. 1). The other sites are also of ecotoxicological concern since the levels of both DDT and DDE exceeded the TEL values at 8 sites mostly located in Velke Kozmalovce and Ruzin water reservoirs. This comparison suggested that the exposure of DDT and DDE might cause ecological risk on the neighboring benthic organisms, including their decreased diversity and abundance as well as behavioural changes, in the studied water reservoirs.

\section{Conclusions}

Concentrations, sources and the potential ecotoxicity of selected organochlorine pesticides (OCPs) were studied in surface sediments of the following water reservoirs: Velke Kozmalovce, Ruzin and Zemplinska Sirava. The results indicated that although the use of most OCPs has been banned in the former Czechoslovakia for more than 20 years, residues of some OCPs still persisted in the surface sediments. HCB, DDT and its metabolite DDE were the most dominant compounds in all sediment samples. Relatively low values of the ratio of DDT/(DDE + DDD) indicated that parent DDT was 
$\mathrm{T}$ a b 1 e 4. Assessment of potential biological risks of selected OCPs in surface sediments from Velke Kozmalovce, Ruzin and Zemplinska Sirava water reservoirs using sediment quality guidelines for freshwater ecosystems.

\begin{tabular}{llllll}
\hline Chemical & Range $\left[\mathrm{ng} \mathrm{g}^{-1}\right]$ & TEL $^{\text {a) }}$ & Above TEL & PEL $^{\text {b) }}$ & Above PEL $^{\mathrm{c}^{c}}$ \\
\hline DDT & bdl-15.8 & 1.19 & 8 & 4.77 & 5 \\
DDE & $1.30-418$ & 1.42 & 8 & 6.75 & 25 \\
DDD & bdl-94.5 & 3.54 & 0 & 8.51 & 1 \\
IDDTs & $1.30-526$ & 7.00 & 26 & 4,450 & 0 \\
\hline
\end{tabular}

a) Threshold effect level, b) Probable effect level, ${ }^{\text {c) }}$ Number of surface sediment samples above the corresponding levels.

degraded significantly to its metabolites and there was no recent input of DDT to the sedimentary environments of these water reservoirs. Based on the comparison of the concentrations measured in this study to the sediment quality guidelines, DDT and DDE should be regarded as the ecotoxicological risk in all three water reservoirs.

Acknowledgements. We thank gratefully the Czech Geological Survey, branch Brno (Czech Republic) and the Water Research Institute Bratislava (Slovak Republic) for helping us to collect sediment samples and performing the analyses.

\section{REFERENCES}

AGARWAL H.C., MITTAL P.K., MENON K.B., PILLAI M.K.K., 1986: DDT residues in the river Jamuna in Delhi, India. Water Air Soil Pollut., 28, 89-104.

AISLABIE J.M., RICHARDS N.K., BOUL H.L., 1997: Microbial degradation of DDT and its residues - a review. New Zeal. J. Agric. Res., 40, 269-282.

BETTINETTI R., CROCE V., GALASSI S., VOLTA P., 2006: p,p'-DDT and p,p'-DDE accumulation in a food chain of lake Maggiore (Northern Italy): Testing steady-state condition. Environ. Sci. Pollut. Res., 13, 59-66.

BOHÁČEK Z., BEZDĚK J., KOVÁŘOVÁ M., HANÁK J., TOUL J., MÜLLER P., 2003: Characteristics of organic matter and contents of some ubiquitous hydrophobic organic pollutants in selected soils and sediments. Bull. Geosci., 78, 179-204.

BREVIK E.M., GRANDE M., KNUTZEN J., POLDER A., SKAARE J.U., 1996: DDT contamination of fish and sediments from lake Ørsjøen, southern Norway: Comparison of data from 1975 and 1994. Chemosphere, 33, 2189-2200.

CCME, 1999: Canadian sediment quality guidelines for the protection of aquatic life: DDT, DDE, and DDD. In: Canadian environmental quality guidelines, 1999, Canadian Council of Ministers of the Environment, Winnipeg.

CHI J., 2009: Vertical fluxes and accumulation of organochlorine pesticides in sediments of Haihe River, Tianjin, China. Bull. Environ. Contam. Toxicol., 82, 510-515.

COVACI A., GHEORGHE A., HULEA O., SCHEPENS P., 2006: Levels and distribution of organochlorine pesticides, polychlorinated biphenyls and polybrominated diphenyl ethers in sediments and biota from the Danube Delta, Romania. Environ. Pollut., 140, 136-149.

COVACI A., GHEORGHE A., VOORSPOELS S., MAERVOET J., REDEKER E.S., BLUST R., SCHEPENS P., 2005: Polybrominated diphenyl ethers, polychlorinated biphenyls and organochlorine pesticides in sediment cores from the Western Scheldt river (Belgium): analytical aspects and depth profiles. Environ. Int., 31, 367-375.

COVACI A., MANIRAKIZA P., SCHEPENS P., 2002: Persistent organochlorine pollutants in soils from Belgium, Italy, Greece, and Romania. Bull. Environ. Contam. Toxicol., 68, 97-103.

ČEPKOVÁ V., MACKOVÝCH D., PILVÁŇOVÁ A., 2003: Všeobecná charakteristika POPs látok. In: Monitoring perzistentných organických látok v Slovenskej republike, Technická správa č. 2, čast' 1, Kapitola 2 (Chriaštel' R., Magulová K., Murín M., Gavora J., eds.). Slovenský hydrometeorologický ústav, Bratislava, s. 9-20, dostupné na: http://www.shmu.sk/File/SLO01G31/1TR2_Monit.pdf

DARKO G., AKOTO O., OPPONG C., 2008: Persistent organochlorine pesticide residues in fish, sediments and water from Lake Bosomtwi, Ghana. Chemosphere, 72, 21-24.

DE LA CAL A., ELJARRAT E., RALDÚA D., DURÁN C., BARCELÓ D., 2008: Spatial variation of DDT and its metabolites in fish and sediment from Cinca River, a tributary of Ebro River (Spain). Chemosphere, 70, 1182-1189.

DOONG R.A., PENG C.K., SUN Y.C., LIAO P.L., 2002: Composition and distribution of organochlorine pesticide residues in surface sediments from the Wu-Shi River estuary, Taiwan. Mar. Pollut. Bull., 45, 246-253.

EDWARDS C.A., 1987: The environmental impact of pesticides. Parasitis, 86, 309-329.

FERNÁNDEZ M., CUESTA S., JIMÉNEZ O., GARCÍA M.A., HERNÁNDEZ L.M., MARINA M.L., GONZÁLEZ M.J., 2000: Organochlorine and heavy metal residues in the water/sediment system of the Southeast Regional Park in Madrid, Spain. Chemosphere, 41, 801-812.

GAGGI C., BACCI E., CALAMARI D., FANELLI R., 1985: Chlorinated hydrocarbons in plant foliage: an indication of the tropospheric contamination level. Chemosphere, 14, 1673-1686.

GUO Y., YUH-Y., ZENG E.Y., 2009: Occurrence, source diagnosis, and biological effect assessment of DDT and its metabolites in various environmental compartments of the Pearl River Delta, South China: A review. Environ. Pollut., 157, 1753-1763.

HILLER E., SIROTIAK M., JURKOVIČ L', ZEMANOVÁ L., 2009: Polycyclic aromatic hydrocarbons in bottom sediments from three water reservoirs, Slovakia. Bull. Environ. Contam. Toxicol., 83, 444-448.

HOAI P.M., NGOC N.T., MINH N.H., VIET P.H., BERG M., ALDER A.C., GIGER W., 2009: Recent levels of organochlorine pesticides and polychlorinated biphenyls in sediments of the sewer system in Hanoi, Vietnam. Environ. Pollut., doi:10.1016/j.envpol.2009.09.018 (In Press).

HONG S.H., YIM U.H., SHIM W.J., OH J.R., VIET P.H., PARK P.S., 2008: Persistent organochlorine residues in estuarine and marine sediments from Halong Bay, Hai Phong 
Bay, and Balat Estuary, Vietnam. Chemosphere, 72, 1193$-1202$.

HU L., ZHANG G., ZHENG B., QIN Y., LIN T., GUO Z., 2009: Occurrence and distribution of organochlorine pesticides (OCPs) in surface sediments of the Bohai Sea, China. Chemosphere, 77, 663-672.

KLÁNOVÁ J., MATYKIEWICZOVÁ N., MÁČKA Z., PROŠEK P., LÁSKA K., KLÁN P., 2008: Persistent organic pollutants in soils and sediments from James Ross Island, Antarctica. Environ. Pollut., 152, 416-423.

KOCAN A., PETRIK J., JURSA S., CHOVANCOVA J., DROBNA B., 2001: Environmental contamination with polychlorinated biphenyls in the area of their former manufacture in Slovakia. Chemosphere, 43, 595-600.

MA X., RAN Y., GONG J., ZOU M., 2008: Concentrations and inventories of polycyclic aromatic hydrocarbons and organochlorine pesticides in watershed soils in the Pearl River Delta, China. Environ. Monit: Assess., 145, 453-464.

MACDONALD D.D., INGERSOLL C.G., BERGER T.A., 2000: Development and evaluation of consensus-based sediment quality guidelines for freshwater ecosystems. Arch. Environ. Contam. Toxicol., 39, 20-31.

MACKOVÝCH D., DÖMÉNYOVÁ J., METELKOVÁ M., 2003: Sedimenty. In: Monitoring perzistentných organických látok v Slovenskej republike. Technická správa č. 2, čast' 1, Kapitola 5 (Chriaštel' R., Magulová K., Murín M., Gavora J., eds.). Slovenský hydrometeorologický ústav, Bratislava, s. 67-77, dostupné na: http://www.shmu.sk/ File/SLO01G31/1TR2_Monit.pdf

MALIK A., OJHA P., SIN̄GH K.P., 2009: Levels and distribution of persistent organochlorine pesticide residues in water and sediments of Gomti River (India) - a tributary of the Ganges River. Environ. Monit. Assess., 148, 421-435.

MENONE M.L., MIGLIORANZA K.S.B., BOTTO F., IRIBARNE O., DE MORENO J.E.A., MORENO V.J., 2006 Field accumulative behavior of organochlorine pesticides. The role of crabs and sediment characteristics in coastal environments. Mar. Pollut. Bull., 52, 1717-1724.

MUIR D.C.G., GRIFT N.P., LOCKHART W.L., WILKINSON P., BILLECK B.N., BRUNSKILL G.J., 1995: Spatial trends and historical profiles of organochlorine pesticides in Arctic lake sediments. Sci. Total Environ., 160/161, 447-457.

PAASIVIRTA J., SINKKONEN S., MIKKELSON P., RANTIO T., WANIA F., 1999: Estimation of vapor pressures, solubilities and Henry's law constants of selected persistent organic pollutants as functions of temperature. Chemosphere, 39, 811-832.

PERIS E., REQUENA S., DE LA GUARDIA M., PASTOR A., CARRASCO J.M., 2005: Organochlorinated pesticides in sediments from the Lake Albufera of Valencia (Spain). Chemosphere, 60, 1542-1549.

PULKRABOVÁ J., SUCHANOVÁ M., TOMANIOVÁ M., KOCOUREK V., HAJŠLOVÁ J., 2008: Organic pollutants in areas impacted by flooding in 2002: A 4-year survey. Bull. Environ. Contam. Toxicol., 81, 299-304.

QIAN Y., ZHENG M.H., ZHANG B., GAO L.R., LIU W.B., 2006: Determination and assessment of HCHs and DDTs residues in sediments from Lake Dongting, China. Environ. Monit. Assess., 116, 157-167.

SMITH S.L., MACDONALD D.D., KEENLEYSIDE K.A., INGERSOLL C.G., FIELD J., 1996: A preliminary evaluation of sediment quality assessment values for freshwater ecosystems. J. Great Lakes Res., 22, 624-638.

SVOBODOVÁ Z., ŽLÁBEK V., RANDÁK T., MÁCHOVÁ J., KOLÁŘOVÁ J., HAJŠLOVÁ J., SUCHAN P., 2003: Profiles of persistent organochlorine pollutants (POPs) in tissues of marketable common carp and in bottom sediments of selected ponds of South and West Bohemia. Acta Vet. BRNO, 72, 295-309.

TOMZA-MARCINIAK A., WITCZAK A., 2009: Bioaccumulation of DDT and its metabolites in the Międzyodrze ecosystem, Poland. Polish J. Environ. Stud., 18, 467-474.

TOUL J., BEZDĚK J., KOVÁŘOVÁ M., BOHÁČEK Z., HANÁK J., MILIČKA J., MÜLLER P., 2003: Sorption of hydrophobic organic pollutants on soils and sediments. Bull. Geosci., 78, 205-223.

VILLAVERDE J., HILDEBRANDT A., MARTÍNEZ E., LACORTE S., MORILLO E., MAQUEDA C., VIANA P., BARCELÓ D., 2008: Priority pesticides and their degradation products in river sediments from Portugal. Sci. Total Environ., 390, 507-513.

WANG F., BIAN Y-R., JIANG X., GAO H-J., YU G-F., DENG J-C., 2006: Residual characteristics of organochlorine pesticides in Lou soils with different fertilization modes. Pedosphere, 16, 161-168.

WANG X-P., YAO T-D., WANG P-L., TIAN L-D., 2008: The recent deposition of persistent organic pollutants and mercury to the Dasuopu glacier, Mt. Xixiabangma, central Himalayas. Sci. Total Environ., 394, 134-143.

WANIA F., MACKAY D., 1995: A global distribution model for persistent organic chemicals. Sci. Total Environ., 160/161, 211-232.

WHO, 1989: DDT and its derivates - environmental aspects. Environmental Health Criteria, No. 83. World Health Organization, Geneva.

WWF, 1999: Hazards and exposures associated with DDT and synthetic pyrethroids used for vector control. World Wildlife Fund, Washington, DC.

ZHAO Z., ZHANG L., WU J., FAN C., 2009: Distribution and bioaccumulation of organochlorine pesticides in surface sediments and benthic organisms from Taihu Lake, China. Chemosphere, 77, 1191-1198.

Received 13 January 2010 Accepted 23 June 2010 